\title{
Toxicity and genotoxicity in Astyanax bimaculatus (Characidae) induced by microcystins from a bloom of Microcystis spp
}

\author{
Ricardo Rocha Pavan da Silva ${ }^{1}$, Osmindo Rodrigues Pires Junior ${ }^{2}$ and Cesar Koppe Grisolia ${ }^{1 *}$ \\ ${ }^{1}$ Departamento de Genética e Morfologia, Instituto de Ciências Biológicas, Universidade de Brasília, \\ Brasilia, DF, Brazil. \\ ${ }^{2}$ Departamento de Ciências Fisiológicas, Instituto de Ciências Biológicas, Universidade de Brasília, \\ Brasilia, DF, Brazil.
}

\begin{abstract}
Studies of genotoxicity in fish caused by cyanobacterial microcystins can be useful both in determining the sensitivity of native species, as well as comparing exposure routes. The genotoxicity caused by the microcystins LR and LA from a bloom collected in a eutrophic lake, was revealed in the fish Astyanax bimaculatus, a native species from South America. LC50 (72 h) was determined as $242.81 \mathrm{gg} \mathrm{L}^{-1}$ and LD50 (72 h) as $49.19 \mathrm{\mu g} \mathrm{kg}^{-1}$ bw. There was a significant increase of DNA damage in peripheral erythrocytes, following intraperitoneal injection (ip) with tested concentrations of $24.58 \mu \mathrm{g} \mathrm{kg}^{-1}$ bw and $36.88 \mu \mathrm{g} \mathrm{kg}^{-1}$ bw, as well as through body exposure to a concentration of $103.72 \mu \mathrm{g} \mathrm{L}^{-1}$. Micronucleus (MN) induction was observed after ip injections of $24.58 \mu \mathrm{g} \mathrm{kg}^{-1}$ bw and $36.88 \mathrm{~g} \mathrm{~kg} \mathrm{k}^{-1} \mathrm{bw}^{-1}$ for $72 \mathrm{~h}$, as well as following body exposure for 72 at $103.72 \mu \mathrm{g} \mathrm{L}^{-1}$. Thus, both exposure routes resulted in MN induction and DNA damage. Apoptosis-necrosis testing was carried out only by ip injection with concentrations of $24.58 \mu \mathrm{g}$ $\mathrm{kg}^{-1}$ bw and $36.88 \mu \mathrm{g} \mathrm{kg}-1 \mathrm{bw}$. Exposure to microcystins at lower concentrations induced more apoptosis than necrosis in peripheral erythrocytes, whereas exposure at higher concentrations gave rise to both conditions. Thus, Astyanax bimaculatus can be considered as a species sensitive to the genotoxic effects caused by microcystins.
\end{abstract}

Key words: microcystin, comet assay, fish micronucleus, necrosis, apoptosis.

Received: December 17, 2009; Accepted: June 29, 2010.

\section{Introduction}

Cyanotoxins are a diverse group of natural toxins produced by cyanobacteria which can be found in lakes, ponds and rivers. They are hepatotoxic, neurotoxic and dermatotoxic, with effects on the inhibition of protein synthesis causing serious ecological and human health problems. Moreover, they are inhibitors of PP1 and PP2 phosphatases, especially in the liver, thereby causing morphological damage, starting with cytoskeletal disruption and loss of sinusoidal structure. Liver weight increases due to intrahepatic hemorrhage, followed by hemodynamic shock, heart failure, and finally death by hemorrhagic shock (Eriksson et al., 1990; Chorus and Bartram, 1999).

Erythrocyte cells from peripheral blood are commonly used for the application of the comet assay in conjunction with micronucleus testing, in fish species exposed to water pollutants (Russo et al., 2004). Astyanax bimaculatus, a nonmigratory native fish species, com-

Send correspondence to Cesar Koppe Grisolia. Departamento de Genética e Morfologia, Instituto de Ciências Biológica, Universidade de Brasília, 70910-900 Brasília, DF, Brazil. E-mail: grisolia@unb.br. monly known as the 'lambari', is widely abundant throughout South America. The species, besides playing a central role in riverine food webs, is sensitive to environmental degradation. These characteristics make it an excellent bio-indicator, through being both commonly present in Brazilian ponds and rivers, as well as a potential target of microcystins from cyanobacterial bloom.

Lake Paranoá, a tropical reservoir, was built in 1959, simultaneous with the construction of the Brazilian capital, Brasilia. Within a decade, the lake became eutrophic due to inadequate sewage treatment associated with high population growth (Altafin et al., 1995). Nutrient input from domestic sewage is still the main source of pollution in Brasília, a city without any chemical industry. The lake is typically eutrophic, with phosphorus representing the limiting nutrient for algal growth (CAESB, 1996). The presence of the cyanotoxin producer Microcystis aeruginosa was revealed through a water-monitoring program undertaken by the $\mathrm{Mu}$ nicipal Drinking Water and Sewage Corporation (CAESB).

The bioaccumulation of microcystins in fish was first observed in salmon after eating crab larvae containing microcystin (Williams et al., 1997) The accumulation in the liver and muscles of $T$. rendalli was demonstrated by 
Soares et al., (2004), who also showed that these toxins could still be found in the muscles of the fish several days after contamination. Astyanax bimaculatus, besides its use as fishing bait, is also a snack-food, an ornamental fish and a larva-eater in combating mosquito larvae. Furthermore, through being herbivorous and phytoplanktivorous, it is incapable of avoiding the ingestion of toxic compounds. The aim hereby was to evaluate the toxicity and genotoxicity to Astyanax bimaculatus, as induced by an extract of cyanobacterial microcystins, using two administration routes and different endpoints, such as micronucleus and apoptosisnecrosis testing, and comet assaying.

\section{Material and Methods}

The specimens of Astyanax bimaculatus used in this study were obtained from a local fish farm, where breeding and sanitary conditions were under constant control and monitoring. The criterion for fish-selection was a bodylength of $7-10 \mathrm{~cm}$. The fishes were acclimatized for a week in $250 \mathrm{~L}$ tanks in the Genetics Laboratory of the University of Brasilia, with continuously aerated, filtered and dechlorinated tapwater. They were kept at constant temperature $\left(25 \pm 2{ }^{\circ} \mathrm{C}\right)$, conductivity $(550 \pm 50 \mu \mathrm{S}), \mathrm{pH}(7.0 \pm 0.5)$ and photoperiod (14:10 light:dark), with twice-a-day feeding with granular fish-chow. The level of ammonium in the water was constantly monitored and the water itself periodically renewed. The fishes, in groups of eight, were ran-

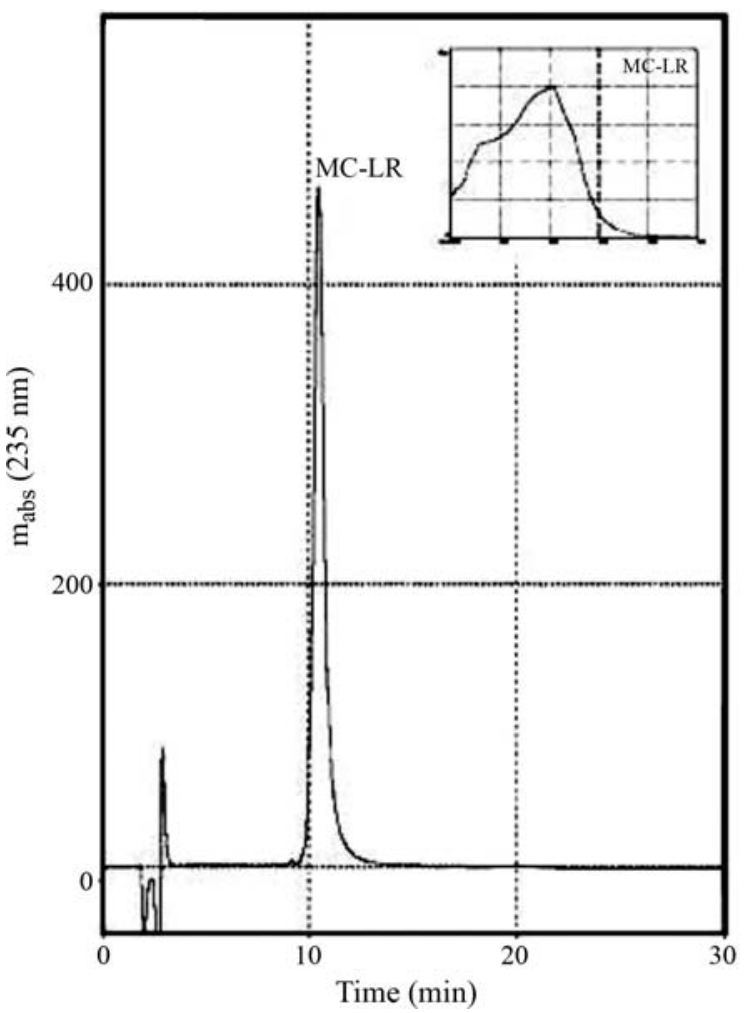

domly placed in glass aquaria of $30 \mathrm{~L}$. Treatments consisted of intraperitoneal (ip) injection and body exposure. To determine the toxicity (LC50-72 $\mathrm{h}$ and LD - $72 \mathrm{~h}$ ) the Trimed Spearman-Karber method was used (Hamilton et al, 1977). Treatments with the extract were undertaken with the following concentrations: $54.2 \mu \mathrm{g} \mathrm{kg}^{-1}$ bw, $36.88 \mu \mathrm{g} \mathrm{kg}^{-1}$ bw, and $24.58 \mu \mathrm{g} \mathrm{kg}^{-1}$ bw for $72 \mathrm{~h}$ in the ip injection, and $103.72 \mu \mathrm{g} \mathrm{L} \mathrm{L}^{-1}$ and $414.90 \mu \mathrm{g} \mathrm{L}^{-1}$ for $72 \mathrm{~h}$ in body-exposure, plus the respective control in each case. Micronucleus tests, comet assays and necrosis versus apoptosis tests were carried out with peripheral-blood erythrocytes. The research project was approved by the Animal Ethical Committee of the University of Brasilia.

\section{Characterization of the extract}

The extract was obtained from bloom collected in Lake Paranoá on June 25, 2006. The flowering material was lyophilized and then sonicated, whereby the cyanobacterium cells were fractured, with the subsequent elimination of toxins. Thereafter, a small aliquot was removed from the sample for characterization by HPLC. The identification of toxins produced by the bloom of Microcystis spp was by comparing the chromatographic fraction for standard microcystin-LR (SIGMA, CO), with the retention time in the chromatography system and index of similarity of the spectrogram in the range of microcystin absorbance of 200 to $300 \mathrm{~nm}$ (Figure 1). Fractions for the two variants

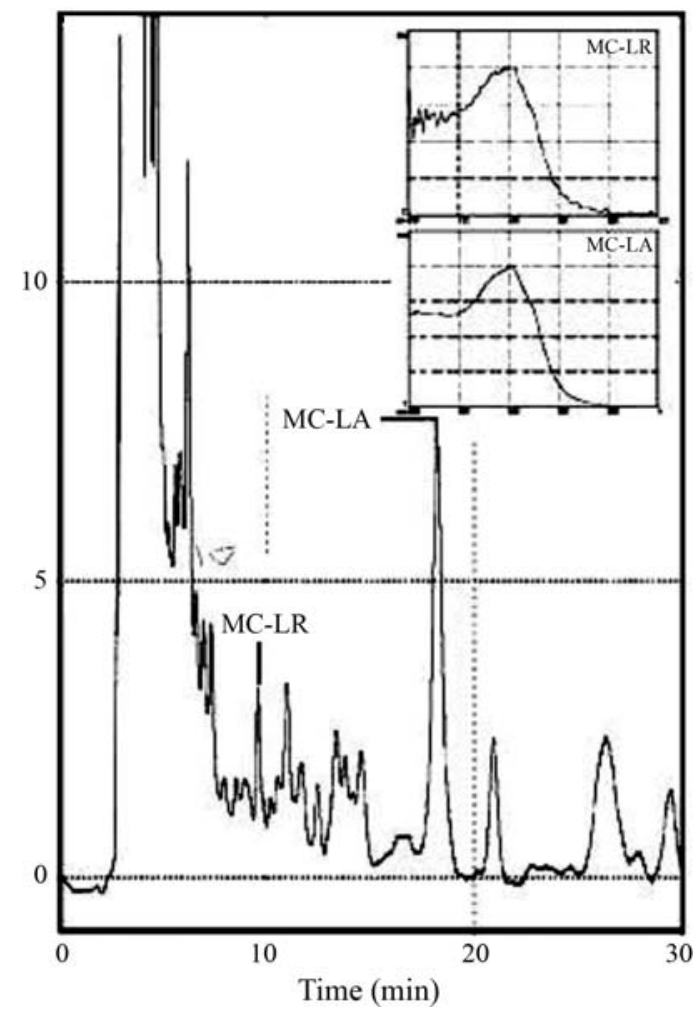

Figure 1 - Chromatogram with standard microcystin-LR (left) and the studied extract from a bloom of cyanobacteria showing the strong presence of microcystin-LR and at second concetration level microcystin-LA (right) 
of microcystin produced by the bloom of Microcystis spp and identified by HPLC-PDA system analysis were fragmented by mass spectrometry - MALDI-TOF/TOF.

A calibration curve for microcystin was prepared from values obtained through chromatographic analysis. The presence of -LR and -LA microcystins was detected by the HPLC system in $300 \mathrm{~mL}$ of Microcystis spp bloom extract. Based on this, the standard curve was calculated from a concentration of $29.19 \mathrm{mg}$ of microcystin-LA and $12.30 \mathrm{mg}$ of microcystin-LR. There was, therefore, a total of $138.3 \mathrm{~g} \mathrm{~mL}^{-1}$ of microcystins in the tested extract. It is noteworthy that other substances can occur in the extract, since the methodology presented is able to detect only the microcystins but no other type of chemical compound.

\section{Micronucleus testing}

Peripheral blood $(50 \mu \mathrm{L})$, obtained by cardiac puncture with a heparinized syringe, was immediately smeared. After fixation in ethanol for $15 \mathrm{~min}$, slides were left to air-dry, whereupon they were stained with acridine orange at a concentration of $0.003 \%$. The stained slides were viewed under an epi-fluorescent microscope at 1000X magnification, and checked for the presence of micronuclei exhibiting yellow-green fluorescence in the peripheral blood erythrocytes. For each treatment, all eight fish were sampled and 3,000 erythrocyte cells with complete cytoplasm were scored per fish (24,000 cells per treatment). The criteria for identifying micronucleated erythrocytes were: (a) MN should be one-third smaller than the main nuclei; (b) MN must not touch the main nuclei; (c) MN must be of the same color and intensity as the main nuclei. These data were statistically analyzed by non-parametric MannWhitney $U$-test, considering $\alpha=5 \%$.

\section{Comet assaying}

This was undertaken as described by Singh et al. (1988), but with certain modifications. The cell-suspension sampled in the microtubule was mixed with $120 \mu \mathrm{L}$ of low melting agarose $\left(37^{\circ} \mathrm{C}\right)$. Then, $500 \mu \mathrm{L}$ of the erythrocyte-agarose suspension were placed onto a fully frosted slide pre-coated with standard agarose $(1.5 \%)$, and covered with a coverslip. The slides were then kept on ice for $15 \mathrm{~min}$ to permit complete agarose polymerization, and afterwards inserted into a chilled lysing solution $(\mathrm{NaCl} 2.5 \mathrm{M}$; EDTA $100 \mathrm{mM}$; Tris $10 \mathrm{mM}$; N-laurolyl-sarcosine 1\%; Triton-X $1 \%$; DMSO 10\%; pH 10). Then the slides were then placed onto a horizontal gel electrophoresis platform and covered with a chilled alkaline solution consisting of $300 \mathrm{mM}$ of $\mathrm{NaOH}$ and $1 \mathrm{mM}$ of $\mathrm{Na}_{2}$ EDTA ( $\mathrm{pH} \mathrm{13}$ ); they were left in the dark at $4{ }^{\circ} \mathrm{C}$ for $30 \mathrm{~min}$, and then the DNA was electrophoresed at $4{ }^{\circ} \mathrm{C}$ in the dark for $30 \mathrm{~min}$ at $25 \mathrm{~V}$ and approximately $350 \mathrm{~mA}$. The slides were gently rinsed twice with $400 \mathrm{mM}$ Tris (pH 7.5) to neutralize the alkali. Each slide was stained with $30 \mu \mathrm{L}$ of $20 \mu \mathrm{g} \mathrm{mL}^{1}$ ethidium bromide and covered with a coverslip. One hundred cells from each replicate were randomly chosen (50 from each duplicate slide), and analyzed under an optical fluorescence microscope (Axioskop-2, Carl Zeiss), with a 510-560 nm filter and a $590 \mathrm{~nm}$ barrier filter, at a magnification of $400 \mathrm{x}$.

For damage index calculation, cells were sorted into four classes, according to tail size. The index of damage (ID) is the sum of the classes of 100 cells analyzed per fish, and may vary from 0 (all the cells are undamaged - 0X100) to 400 (all the cells are highly damaged - 4X100). The damage index is based on the length of migration and the amount of DNA in the tail, and it is considered a sensitive measurement of detectable DNA damage. Statistical analysis was carried out with the MINITAB program, using the ANOVA parametric test and Tukey parametric linear correlation, with a significance level of $95 \%$. The following formula was used to quantify DNA damage:

$$
I D_{a u}=\frac{N 1+2 N 2+3 N 3+4 N 4}{S / 100}
$$

where $I D$ is the index of DNA damage, $a u$ an arbitrary unit, $N 1-N 4$ the nucleoids in levels 1,2,3 and 4, $S$ the number of nucleoids analyzed, including level 0 .

\section{Apoptosis-necrosis testing}

Treatments were carried out in groups of eight fishes through the intraperitoneal injection of an extract of Microcystis spp at $36.88 \mu \mathrm{g} \mathrm{kg}^{-1}$ bw and $24.58 \mu \mathrm{g} \mathrm{kg}^{-1}$ bw for $72 \mathrm{~h} .0 .1 \mathrm{~mL}$ of peripheral blood was obtained from cardiac puncturing and diluted in $2.0 \mathrm{~mL}$ of fetal bovine serum at room temperature $\left(22 \pm 2{ }^{\circ} \mathrm{C}\right) .15 \mu \mathrm{L}$ of cell suspension was immediately smeared onto slides, whereupon $1 \mu \mathrm{L}$ of acridine orange/ethidium bromide (1:1) stain was added and the slides covered with a coverslip. The slides were analyzed with a fluorescence Axioskop 2 Zeiss microscope at 1000X magnification using a wavelength of 510-560 nm. Five hundred peripheral erythrocytes were analyzed and classified as viable, necrotic or apoptotic. Results were statistically analyzed by t-test, with significance of 0.05 .

\section{Results}

In the toxicological test of LD 50 with $A$. bimaculatus, 6 out of 10 fishes died after ip application at a concentration of $54.20 \mu \mathrm{g} \mathrm{kg}^{-1} \mathrm{bw}$, thus making this unfeasible for evaluating genotoxicity. Low mortality was observed in the concentrations $24.58 \mu \mathrm{g} \mathrm{kg}^{-1}$ bw and $36.88 \mu \mathrm{g}$ $\mathrm{kg}^{-1} \mathrm{bw}$, with 2 deaths out of 10 fishes exposed in each concentration. LD50 (72 h) was determined as $49.19 \mu \mathrm{g} \mathrm{kg}^{-1}$ at a confidence interval of $38.58 \mu \mathrm{g} \mathrm{kg}^{-1}-62.73 \mu \mathrm{g} \mathrm{kg}{ }^{-1}$. The LC50 (72 h) was determined as $242.81 \mu \mathrm{g} \mathrm{kg}^{-1}$ with a confidence interval of 152.74-386.00 $\mu \mathrm{g} \mathrm{L}^{-1}$. In the micronucleus tests, exposure via ip was statistically significant for both tested microcystin concentrations of $24.58 \mu \mathrm{g} \mathrm{kg}^{-1}$ and $36.88 \mu \mathrm{g} \mathrm{kg}^{-1} \mathrm{bw}$. Body exposure experimenting also 
showed micronucleus induction at a concentration of $103.72 \mu \mathrm{g} \mathrm{L}^{-1}$ (Table 1). Comet assaying also revealed genotoxicity along both routes of exposure (Table 2). Apoptosis-necrosis testing showed that only apoptotic erythrocyte cells were found at lower concentrations, whereas both necrosis and apoptosis were found at the higher ones (Table 3 ).

\section{Discussion}

Several well-known exotic species of fish are worldwide exposed to mutagens in water and used as bioindicators of genotoxicity, such as Oreochromis niloticus, Cyprinus carpio, Danio rerio, Carassius auratus, etc. However, in field situations, pollutants dissolved or suspended in the water require an appropriate native species as in situ bioindicator. Much evidence has indicated that not only mammals are susceptible to cyanotoxins, but fish as well (Jos et al., 2005). In cyanobacteria blooms, deaths of fish were observed mainly involving planktivorous species, such as Cyprinus carpio (Rodger et al., 1994). Fisher and Dietrich (2000) showed the pathological and biochemical characterization of microcystin-induced hepatopancreas and kidney damage in carp (Cyprinus carpio).

Andersen et al. (1993) reported mortality at $555 \mathrm{pg} \mathrm{kg}^{-1}$ in salmon (Salmo salur) injected three times via ip with microcystin-LR. In rainbow trout the LD50 of microcystin-LR is between 400 and $1000 \mathrm{mg} \mathrm{kg}^{-1}$ (Kotak et al., 1996). In our study, the LC50 and LD50 observed in $A$. bimaculatus were $242.81 \mathrm{mg} \mathrm{L}^{-1}$ and $49.19 \mu \mathrm{g} \mathrm{kg}^{-1} \mathrm{bw}$, respectively, thus demonstrating a considerable difference in susceptibility to microcystin-LR in this species. In addition, the fishes' nutritional and physiological conditions can have an affect on cyanotoxin toxicity (Rabergh et al., 1991). Normally, the effect of oral administration of a toxicant is approximately 10 times less than via ip (Carbis et al, 1996). Zhao et al. (2006) found a consumption of 1500$6000 \mu \mathrm{g} \mathrm{kg}^{-1}$ bw of microcystin by tilapia to be equivalent to $150-600 \mu \mathrm{g} \mathrm{kg}^{-1}$ bw injected via ip, this without affecting the growth or feeding rate of the species. In a species of carp (Carassius auratus gibelio) high mortality occurred when fish were fed on diets containing low doses of microcystin (1.02-10.76 $\mathrm{g} \mathrm{kg}^{-1} \mathrm{bw}$ ) (Zhao et al., 2005).

Table 1 - Means (SD) of micronuclei in Astyanax bimaculatus after treatment with extracts at different concentrations, considering two exposure routes.

\begin{tabular}{lccc}
\hline Treatments & Exposure route & MN (Mean \pm SD) & P Mann Whitney-U test \\
\hline Control & & $0.6 \pm 0.7$ & $0.002 *$ \\
$103.72 \mu \mathrm{g} / \mathrm{L}$ & Body exposure & $2.9 \pm 1.85$ & $0.008 *$ \\
$24.58 \mu \mathrm{g} \mathrm{kg}^{-1}$ bw & i.p. & $2.5 \pm 1.41$ & $0.024 *$ \\
$36.88 \mu \mathrm{g} \mathrm{kg}^{-1}$ bw & i.p. & $3.5 \pm 2.62$ & \\
\hline
\end{tabular}

*Significant at level of $5 \%$.

Table 2 - Means (SD) of DNA damage index obtained from comet assay from peripheral erythrocytes of Astyanax bimaculatus after treatment with extracts with different concentration, considering two exposure routes.

\begin{tabular}{lccc}
\hline Treatments & Exposure route & DNA damage (Mean \pm SD) & P Mann Whitney-U test \\
\hline Control & & $30.57 \pm 16.03$ & $0.0004 *$ \\
$103.72 \mu \mathrm{g} / \mathrm{L}$ & Body exposure & $205.30 \pm 38.41$ & $0.0046 *$ \\
$24.58 \mu \mathrm{g} \mathrm{kg}^{-1}$ bw & i.p. & $70.13 \pm 29.49$ & $0.0012 *$ \\
$36.88 \mu \mathrm{g} \mathrm{kg}^{-1}$ bw & i.p. & $122.27 \pm 26.16$ & \\
\hline
\end{tabular}

*Significant at level of $5 \%$.

Table 3 - Means (SD) of viables, necrotic and apoptotic peripheral erythrocyte cells of Astyanax bimaculatus and their respective percentages after ip injection of extracts of Microcystis spp.

\begin{tabular}{lcccccc}
\hline Treatments & Viable & Necrosis & Apoptosis & \% Viability & \% Necrosis & \% Apoptosis \\
\hline Control & $473.9 \pm 29.3$ & $20.9 \pm 28.9$ & $5.3 \pm 3.6$ & 94.8 & 4.2 & 1.1 \\
$24.58 \mu \mathrm{g} \mathrm{kg}^{-1}$ bw & $266.1 \pm 155$ & $18.4 \pm 15.6$ & $16.6 \pm 9.9$ & 87.4 & 6.0 & $5.5^{*}$ \\
$36.88 \mu \mathrm{g} \mathrm{kg}^{-1}$ bw & $79.1 \pm 10$ & $15.6 \pm 9.1$ & $5.4 \pm 1.6$ & 79.1 & $15.6^{*}$ & $5.4^{*}$ \\
\hline
\end{tabular}

*Significant at level of $5 \%$. 
In $\mathrm{MN}$ tests, significant statistical differences were found for both routes of exposure. Only one concentration $\left(103.72 \mu \mathrm{g} \mathrm{L}^{-1}\right)$ was used for body exposure testing, as this was considered to be the maximum tolerated dose when based on the LC50. A. bimaculatus proved to be more sensitive to MN induction through ip than through body exposure. Comet assaying has been successfully applied under both laboratory and field conditions, through being a nonspecific, sensitive, rapid and economical biomarker in the detection of genetic damage in natural biota (Jha, 2008). This author also inferred that comet assaying is capable of detecting oxidized DNA bases in fishes exposed to environmental contaminants. The metabolism of microcystins in animals gives rise to the formation of reactive oxygen species, such as superoxide anion radicals, hydrogen peroxide and hydroxyl radicals (Ding et al., 2000, 2001). Comet results followed the MN results, also demonstrating a dose-effect relationship in ip exposure. Though intraperitoneal injection is an inappropriate route for fish models in genotoxicity studies, it normally bestows a more precise exposure level to studied toxins, and therefore better response, than through aquatic exposure.

Apoptosis due to DNA oxidative damage by microcystins in animal cells has been extensively reported both in vivo and in vitro (Gehringer, 2004). Yin et al. (2006) showed that microcystins induce oxidative damage in tobacco BY-2 cells exposed in vitro. In apoptosis-versusnecrosis assaying, we observed that microcystin exposure at the highest concentration induced a statistically significant level of both necrosis and apoptosis, whereas only apoptosis occurred on exposure at the lowest concentration. Our data showed that a microcystic extract, when in low concentrations, could activate cellular oxidative stress, thereby causing genotoxicity but not toxicity, as proposed by several of the above cited authors. Obviously, cell-death by necrosis occurred due to exposure to a high concentration of a well-known toxic compound. Therefore, cyanobacterial bloom in ponds represents a genotoxic risk to fish, and consequently to human health, due to bioaccumulation.

\section{Acknowledgments}

The authors wish to thank the University of Brasilia, the Brazilian National Research Council (CNPq) and Fish Farm Granja do Ipê (Zoobotanical Foundation of Brasilia Municipality) for their support.

\section{References}

Altafin IG, Mattos GGB, Cavalcanti V and Estuqui R (1995) Limnology and recovery program. In: Tundisi JG, Bicudo CEM and Tundisi-Matsumura T (eds) Limnology in Brazil - Paranoá Lake. ABC/SBL, Rio de Janeiro, pp 325-349.

Andersen RJ, Luu HA, Holmes CFB, Kent ML, Leblanc L, Taylor FJR and Williams DE (1993) Chemical and biological evidence links microcystins to salmon "netpen liver disease". Toxicon 31:1315-1323.
Carbis CR, Rawlin GT, Mitchell GF, Anderson JW and McCauley I (1996) The histopatology of carp, Cyprinus carpio L., exposed to microcystins by gavage, immersion and intraperitoneal administration. J Fish Disease 19:199207.

Chorus L and Bartram J (1999) Toxic cyanobacteria in water: A guide to their public health consequences, monitoring and management. World Health Organization, London, 400 pp.

Companhia de Água e Esgoto de Brasília (CAESB) (1996) Avaliação da qualidade sanitária do pescado do Lago Paranoá (Brasília, DF). ISDF/UnB/CAESB and IBGE, Brasília, $48 \mathrm{pp}$.

Ding WX, Shen H-M and Ong CN (2000) Critical role of reactive oxygen species and mitochondrial permeability transition in microcystin-induced rapid apoptosis in rat hepatocytes. Hepatology 32:547-555.

Ding WX, Shen H-M and Ong CN (2001) Critical reactive oxygen species formation in microcystin-induced cytoskeleton disruption in primary cultured hepatocytes. J Toxicol Environ Health 64:507-519.

Eriksson JED, Toivola JAO, Meriluoto IL, Karaki Y, Han D and Hartsborne F (1990) Hepatocycte deformation induced by cyanobacterial toxins reflects inhibition of protein phosphatases. Biochem Biophys Res Commun 173:1347-1353.

Fisher WJ and Dietrich DR (2000) Pathological and biochemical characterization of Microcystin-induced hepatopancreas and kidney damage in carp (Cyprinus carpio). Toxicol Appl Pharmacol 164:73-81.

Gehringer MM (2004) Microcystin-LR and okadaic acid induced cellular effects: A dualistic response. FEBS Lett 577:1-8.

Hamilton MA, Russo RC and Thurston RV (1977) Trimed Spearman-Karber method for estimation median lethal concentration in toxicity bioassays. Environ Sci Technol 11:714-719.

Jha AN (2008) Ecotoxicological applications and significance of the comet assay. Mutagenesis 23:207-221.

Jos A, Pichardo S, Prieto AI, Repetto G, Vázquez CM, Moreno I and Cameán AM (2005) Toxic cyanobacterial cells containing microcystins induce oxidative stress in exposed tilapia fish (Oreochromis sp.) under laboratory conditions. Aquat Toxicol 72:261-271.

Kotak BJ, Semalulu S, Friytz DL, Prepas EE, Hrudey SE and Coppock RW (1996) Hepatic and renal pathology of intraperitoneally administered microcystin-LR in rainbow trout (Oncorhynchus mykiss). Toxicon 34:517-525.

Rabergh CMI, Bylund G and Eriksson JE (1991) Histopathological effects of microcystin-LR, a cyclic peptide toxin from the cyanobacterium (bluegreen algae) Microcystis aeruginosa, on common carp (Cyprinus carpio L.). Aquat Toxicol 20:131-146.

Rodger HD, Turnbull T, Edwards C and Codd GA (1994) Cyanobacterial (blue green algal) bloom associated pathology in brown trout, Sulmo trutta L. J Fish Disease 8:177-181.

Russo C, Rocco L, Morescalchi MA and Stingo V (2004) Assessment of environmental stress by the micronucleus test and the Comet assay on the genome of teleost populations from two natural environments. Ecotoxicol and Environ Saf 57:168-174.

Singh NP, McCoy MT, Tice RR and Schneider EL (1988) A simple technique for quantitation of low levels of DNA damage in individual cells. Exp Cell Res 175:184-191. 
Soares RM, Magalhães VF and Azevedo SMFO (2004) Accumulation and depuration of microcystins (cyanobacteria hepatotoxins) in Tilapia reandalli (Cichlidae) under laboratory conditions. Aquat Toxicol 70:1-10.

Williams DE, Craig M, Dawe SC, Kent ML, Holmes CFB and Andersen RJ (1997) Evidence for a covalentely bound form of microcystin-LR in salmon liver and Dungeness crab larvae. Chem Res Toxicol 10:463-469.

Yin LB, Huang J, Li W and Liu Y (2006) Microcystin-RRinduced apoptosis in tobacco BY-2 cells. Toxicon 48:204210 .
Zhao M, Xie S, Zhu X, Yang Y, Gan N and Song L (2005) Effect of inclusion of blue-green algae meal on growth and accumulation of microcystins in gibel carp (Carassius auratus gibelio). J Appl Ichthyol 22:72-78.

Zhao M, Xie S, Zhu X, Yang Y, Gan N and Song L (2006) Effect of dietary cyanobacteria on growth and accumulation of microcystins in Nile tilapia (Oreochromis niloticus). Aquaculture 261:960-966.

Associate Editor: Catarina S. Takahashi

License information: This is an open-access article distributed under the terms of the Creative Commons Attribution License, which permits unrestricted use, distribution, and reproduction in any medium, provided the original work is properly cited. 